\title{
What Drives Mutual Funds Long-term Herding: Bear or Bull Markets?
}

\author{
G. Rubbaniy ${ }^{1}$ \\ ${ }^{1}$ College of Business, Zayed University, PO Box 144534, Khalifa, City, Abu Dhabi, UAE \\ Crrespondence: G. Rubbaniy, College of Business, Zayed University, PO Box 144534, Khalifa, City, Abu Dhabi, \\ UAE
}

Received: October 18, 2016

Accepted: November 14, 2016

Online Published: November 22, 2016

doi:10.5430/afr.v5n4p214

URL: http://dx.doi.org/10.5430/afr.v5n4p214

\begin{abstract}
This paper explores the herding dynamics in US mutual funds' trading and documents the evidence of increased herding over time. I observe (slightly) higher levels of overall herding compared to main stream herding literature with asymmetry on the buy and sell side; the overall herding level is weakly affected by the scale economies and significantly influenced by a fund's style. Increased participation of mutual funds to the financial markets, proxied by number of quarterly traded securities, appears to be positively correlated with mutual funds' herding. Both stocks' beta and market volatility are found to be crucial determinants of herding. A higher demand for the smaller-sized stocks confirms the presence of small-firm-effect anomaly. In addition, I find US mutual funds' herding more in bad market scenarios compared with good market environment.
\end{abstract}

Keywords: Realized volatility, Mutual funds, Herding Behaviour, Financial markets

JEL classification: D7, F3, G12

I acknowledge the support of Erasmus University Rotterdam, Netherlands in terms of data provision.

\section{Introduction}

For the last two decades, the financial world has changed quite rapidly, as more problems have emerged for researchers studying the behavior of the financial markets and its determinants. During the last decade, I have witnessed two of the worst economic episodes, the dotcom bubble of 1999-2001 and the global financial crisis of 2007-2009. The global financial crisis has generally been considered the worst since the Great Depression of 1929 and has severely affected the major economies of the world, leading many previously strong institutions to default (e.g., Lehman Brothers, Bear Stearns, Merrill Lynch). Having eroded a substantial portion of the world's financial wealth, these crises have exposed the vulnerability of institutional investors to many significant risks (Note 1) and forced financial analysts, professionals and academics to more carefully analyze both the potential micro and macro factors that may affect stock prices. One of these potential factors is the trading behavior of institutional investors.

Due to an enormous increase in their financial wealth over the last few decades (Note 2), institutional traders have attracted the focus of academics and financial professionals; the relationship between institutional investments and stock prices has been of particular interest. Some of the main players among institutional traders are mutual funds (MFs). This growing industry has attracted more than 4 trillion US dollars by the end of 2007 Glode (2011), with a tremendous compounded annual growth rate of $16 \%$ from 1980 to 2008 Wahal and Wang (2011). Because MFs compose a significant portion of institutional wealth, their trading behavior mimics the general investment behavior of institutional investors.

Given the importance of MFs trading behaviour, existing literature already explored some important features for instance herding in trading behaviour of MFs, which is documented to have significant effect on security prices. However, while exploring the presence of herding in institutional investment behavior, no study has specifically focused on the dynamics of herding and its determinants. I attempt to fill this gap by investigating whether institutional herding has an increasing trend overtime; if yes, what are its determinants? More specifically, I investigate whether MFs' levels of herding change over time? If yes, do herds emerge and become dominant in periods of substantial price movements? Are herding levels change across MFs and stocks' characteristics? 
I attempt to answer these questions and contribute to the existing literature in several ways. First, I investigate herding over time and provide empirical evidence of increased herding in the trading behavior of institutional investors. Second, I focus on mutual funds' styles, market capitalization, participation in the financial markets and market realized volatility as determinants of significant herding over time. Third, I analyze the herding behavior of MFs during both bull and bear markets to see whether herding in the trading behavior of MFs co-moves with market conditions. Last, I extend the existing literature on the characteristics of herding, for instance, stocks' sensitivity to market movements (beta).

Using data comprising all stocks listed on the NYSE, NASDAQ and AMEX that were held in the portfolio holdings of US equity MFs over the period January 1980 to December 2009, I explore the herding dynamics in US MFs' trading and document the evidence of increased herding over time. I observe (slightly) higher levels of overall herding compared with the mainstream literature, with asymmetry on the buy and the sell side; the overall herding level is weakly affected by scale economies and significantly affected by funds' styles. Increased participation of MFs in the financial markets, proxied by quarterly traded securities, is positively correlated with quarterly average herding. Both a stock's beta and market volatility are found to be crucial determinants of herding. I find US MFs' herding more in bearish scenarios compared to bullish environments.

The remainder of this article is organized as follows: Section 2 discusses the mainstream literature to provide the motivation behind this research. Section 3 focusses on research design and methodology I used to collect data, develop hypothesis and to construct the model. In Section 4, empirical results are presented and finally Section 5 concludes.

\section{Literature Review}

Price impact literature shows that institutional trading affects security prices - see, for instance, S. Dasgupta et al. (2010); Grinblatt, Titman, and Wermers (1995); Nofsinger and Sias (1999); Patterson and Sharma (2004); (Puckett \& Yan, 2008); Sias (2004); Wermers (1999) - but the direction of the effect is still not conclusive. Some studies document that institutional trading stabilizes security prices (Nofsinger \& Sias, 1999; Sias, 2004; Wermers, 1999), while others advance the idea of a destabilizing effect of institutional trading on security prices (A. Dasgupta, Prat, \& Verardo, 2011; Patterson \& Sharma, 2004; Puckett \& Yan, 2008). Most of these studies use feedback trading and herding as trading strategies to gauge the relationship between institutional trading and security price movements. Herding refers to any mass movement into (or out of) some specific stocks for whatever reason Falkenstein (1996) and is a special case of feedback trading. Despite the perceptions of market watchers and herding theories, empirical evidence on herding is mixed; i.e., the evidence differs as to the documentation of the magnitude/level of herding across institutions and over time. For instance, Lakonishok, Shleifer, and Vishny (1992) study US pension funds' quarterly data during the period 1984-1988 using feedback strategies in 769 US pension funds and find an insignificant presence of herding. Their computed herding value is documented to be as little as 2.7 percent. Economically, this number translates as follows: if $100 \mathrm{MFs}$ are active in the same security in the same month, then 2.7 more MFs are trading on the same side of the market than would be expected under the null hypothesis of random selection of securities. Grinblatt et al. (1995) investigate herding using quarterly data of $274 \mathrm{MFs}$ ' holdings over the period 1975-1984 and find economically insignificant levels of herding in US MFs, with a herding level reported to be 2.29 percent. Furthermore, these herding levels vary cross-sectionally across different styles of MFs. Wermers (1999) investigates herding and feedback strategies in US MFs over a relatively longer time span, from 1975 to 1994, and finds slightly higher herding levels, approximately 3.4 percent. His conclusion is consistent with the theory that institutional trading stabilizes security prices by concluding a speedy price-adjustment process spurred by institutional trades. More recently, Sias (2004) and Pirinsky (2002) use different methodologies to find significant levels of herding in an average stock by US institutional investors. Compared with the older studies, Sias (2004) concludes that the use of different herding measures, rather than different sample periods, matters more in finding different herding levels in institutional investments. He measures herding over a longer sample period but does not consider the financial markets' high volatility periods in his conclusion. Recently, Patterson and Sharma (2004) investigate herding in institutional investors' trading behavior using quarterly frequency data over the turbulent period of 1999-2001 and find considerable herding in general and in technology stocks in particular. They also find herding asymmetry on the buy and the sell side and explain that institutional buy-herding destabilizes stock prices, but that institutional sell-herding helps adjust stock prices to their fundamentals. Though Patterson and Sharma (2004) attempt to explain the herding behavior of institutional investors during down markets, they restrict themselves to technology stocks only. The studies of Puckett and Yan (2008) and S. Dasgupta et al. (2010) are also consistent with the idea of stronger herding in institutional trading. Though Sias (2004) offers a herding measure unaffected by the sample period of the data sample, the chronological comparison of these studies reveals changing quantitative levels (magnitude) of herding over time and across institutions. The extant studies - see, for instance, (Grinblatt et al., 1995); Lakonishok et al. (1992), and 
Wermers (1999) - find a weak level of herding, while more recent studies Patterson and Sharma (2004); Puckett and Yan (2008) and S. Dasgupta et al. (2010) document somewhat stronger levels. The studies that include recent periods in their data samples document slightly higher levels of mutual fund herding. Inclusion of a longer sample period and the implicit presence of financial turmoil in their data samples could be the driving force behind the higher levels of herding in their findings. Choe, Kho, and Stulz (1999) document decreased herding and feedback trading during the Korean economic distress (1996-1997), while Hwang and Salmon (2004) find herding levels reduced during the Asian and Russian crises. Moreover, financial commentators have often claimed that herding has increased over time, but they have not yet found any empirical support for their claims. (Note 3) These observations may be a starting point to explore interesting questions include whether incentives to herd co-move with market characteristics such as volatility.

MFs may have a comparative advantage in holding securities with certain characteristics so that when a security acquires these characteristics, its aggregate demand increases. Extant literature reports that certain characteristics of stocks drive MFs' demand, such as a non-linear preference for high-volatility stocks and an aversion to low-price stock Falkenstein (1996), resulting in an increased demand for large and liquid stocks Gompers and Metrick (1998b), a tendency to hold growth stocks Frazzini and Lamont (2008), and a reduced desire for stocks with little information (Falkenstein, 1996). The demand for a stock may change not only because of its idiosyncratic risk but also because of its correlation with market risk, i.e., a stock's beta. Studies documenting herding on a stock's beta seem nonexistent in the literature.

In summary, the existing literature on herding can be characterized into two clear strands. The first strand focuses on tracing the presence of herding in institutional trading behavior, and the second strand investigates the impact of institutional herding on stock prices. When exploring the presence of herding in institutional investment behavior, no study has specifically focused on the dynamics of herding and its determinants. I attempt to fill this gap by investigating whether market conditions, fund characteristics and stock characteristics can be determinants of increasing herding over time. With these objectives and considering the statements of financial commentators, changing herding levels over different sample periods, the trading behavior of MFs during market downturns and the non-exhaustive literature on stocks' characteristic herding, I raise some important questions to investigate: Do MFs' levels of herding change over time? Do herds emerge and become dominant in periods of substantial price movements? Do MFs limit themselves, in the long term, only to specific stocks?

\section{Research Design and Methodology}

\subsection{Data and Descriptive Statistics}

Most of the data for this research comes from Thomson Financial, formerly known as CDA/Spectrum, and has been used in many empirical studies, such as those by (Grinblatt \& Titman, 1989, 1993) and (Daniel, Grinblatt, Titman, \& Wermers, 1997; Ding \& Wermers, 2004; Wermers, 2000). The database covers almost all historical domestic MFs plus approximately 3,000 global funds that hold a fraction of assets in stocks traded on US exchanges and well-known Canadian stock markets since 1980; the dataset is claimed to be largely free of survivor bias, as it includes all the equity funds over the known period Carhart (1997). I restrict ourselves to domestic equity funds and classify them into growth, aggressive growth, growth \& income, balanced and unclassified funds. (Note 4) Regarding asset classes, MFs' holdings are determined through quarterly observations of both fixed income and equity holdings, but I choose to analyze only equities because I want to compare our results with previous studies as well. According to the Investment Company Act of 1940, the US SEC requires all institutional investors with assets of more than $\$ 100$ million under management to submit a report on detailed equity positions if their portfolio holdings contain more than 10,000 shares or amount to a market value of $\$ 20,000$ within 60 to 90 days after the end of a calendar quarter. Thomson Financial makes appropriate adjustments for CUSIP changes, stock splits, and other stock distributions from the holdings data. Our dataset comprises asset positions, share prices (size), quarterly assets, changes in asset positions, purchases, sales and holding periods. I use the calendar quarter as the unit of time. To proxy the market realized volatility, I calculate the volatility of the S\&P 500 Index as an indicator of good and bad market situations. I consider the good (bad) period to be proxied by a quarter in which volatility is low (high) and returns are higher (lower). Our sample comprises quarterly observations for firms listed on the NYSE, NASDAQ and AMEX over the period Jan. 1980 to Dec. 2009. I use daily price data from the CRSP to calculate quarterly abnormal returns and stocks' sensitivity to market risk (Beta).

Figure 1 shows the quarterly dynamics of the number of MFs and the number of securities traded by the MFs. I notice a high positive correlation between the number of active MFs and the number of securities they trade over time, implying that the more that MFs emerge in the markets, the higher the number of securities they explore for trading. 


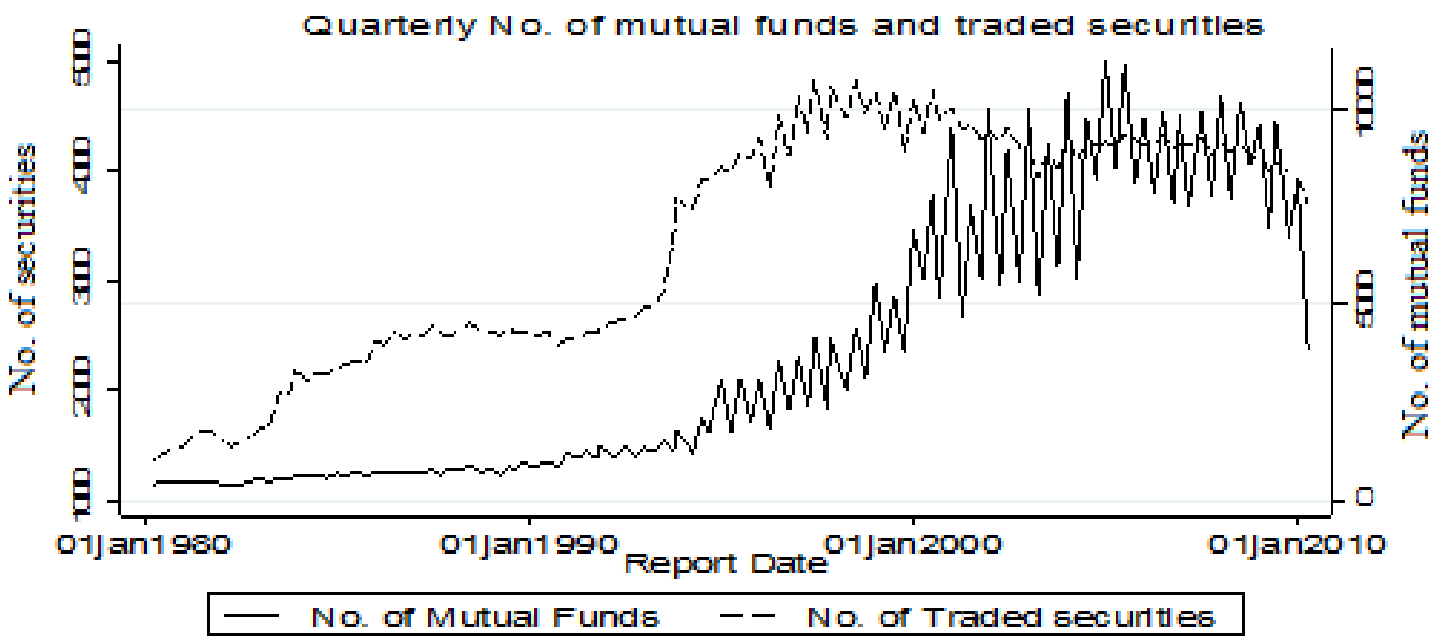

Figure 1. Quarterly number of traded securities and number of mutual funds

Notes: Figure 1 reports the evolution of the number of mutual funds and the number of securities per quarter. Number of securities and number of mutual funds are on the $\mathrm{Y}$-axis, and time span in the quarter is on the $\mathrm{X}$-axis.

Source: Thomson Financial/CDA-Spectrum

The average number of stocks traded by MFs per quarter is approximately 30 (varying from 1,362 to 4,816), and the number of average active MFs per quarter is 560 (fluctuating from 404 to 11,220) over the sample period.

\subsection{Hypotheses and Model}

Our investigation commences with the computation of the Lakonishok et al. (1992) herding measure (LSV), which is defined as:

$$
L S V_{i, t}=\left|\frac{B_{i, t}}{N_{i, t}}-P_{t}\right|-A F_{i, t}
$$

Here, $L S V_{i, t}$ is the herding measure for $i$ th security at time $t, B_{i, t}$ is the number of MFs buyers of $i t h$ security at time $t$ and follows a binomial distribution with probability of success $P_{t}, P_{t}$ is the expected number of buyers at time $t, N_{i, t}$ is the total number of active MFs for $i t h$ security at time $t$ and $A F_{i, t}$ is the adjustment factor to allow for random variation around $P_{t}$ under the null hypothesis of independent decisions by the MFs and is the expected value of $\left|B_{i, t} /\left(N_{i, t}\right)-P_{t}\right|$. The overall herding measure $L S V$ is the average of $L S V_{i, t}$ over all securities and periods. A positive value of herding significant under the T-test will support the evidence of herding in MFs under the normality assumption. I also apply a filter to the sample data prior to computing $L S V$, i.e., two or more MFs must be active in a security quarter for the security to be included in the $L S V$ calculation during that quarter.

One of our main objectives is to explore whether herding exhibits positive innovation over time; therefore, I run a time-series regression of time-effect on herding by using the $L S V$ herding measure as the dependent variable as follows:

$$
L S V_{t}=\beta_{0}+\beta_{1} T+\varepsilon_{t}
$$

A positive effect of time on herding levels leads us to extend our investigation to the potential factors that play a part in positive innovation to herding levels over time. Some of these potential factors include the experience curve effect, increased participation of the MF industry, an increased number of securities traded by these MFs and increased market volatility over time. Usually, MFs hire sophisticated qualified professionals for their portfolio management who make use of increased financial knowledge and cutting-edge IT tools to quickly incorporate new information into security prices. The increasing use of state-of-the-art electronic commerce IT, easy access to financial information and enhanced exposure through investment operations add to portfolio managers' financial knowledge and investment skills over time. This learning-curve effect may lead portfolio managers to extract similar signals for the same security 
at the same time, and therefore, their herding level may increase over time. A lower number of available securities to trade in a certain quarter can limit the MFs' trading choices and may cause concentration of MFs. Alternatively, a higher number of active MFs in the financial markets may increase the competition to explore more profitable stocks and may add to the number of traded securities in a certain quarter. I find a high correlation between the quarterly number of participants in the mutual fund industry and the number of securities they trade, which leads us to analyze only one of these potential factors (see Appendix A). A final potential factor is the volatility of the market in which MFs operate. Some studies document that institutional trading affects security prices and in turn exacerbates market volatility (Stanley, Gabaix, Gopikrishnan, \& Plerou, 2006). I look at the alternative and assume that market volatility has an impact on managers' risk preferences and can explain mutual fund herding over time. I do not use regression models in our analysis; rather, I focus on a decile analysis of different factors to explore insights into the explanatory factors for herding.

Average herding does not communicate anything about whether herds are more on the buy or the sell side of the traded stocks. This phenomenon is documented as herding asymmetry and has been observed when institutions trade into and out of securities Patterson and Sharma (2004). In addition to the variables affecting overall herding, herding asymmetry may also vary significantly over time. I follow Grinblatt et al. (1995) to discern between buy (BLSV) and sell (SLSV) sub-herding measures using the following equations:

$$
B L S V_{i, t}=\left|\frac{B_{i, t}}{N_{i, t}}-P_{t}\right|-A F_{i, t} \text { if } \frac{B_{i, t}}{N_{i, t}}>P_{t}
$$

and

$$
S L S V_{i, t}=\left|\frac{B_{i, t}}{N_{i, t}}-P_{t}\right|-A F_{i, t} \text { if } \frac{B_{i, t}}{N_{i, t}}<P_{t}
$$

I replicate the above methodology to explore whether the above explained variables affect MFs' herding differently when trading into and out of securities over time.

Our period of investigation is long enough to encompass different macroeconomic environments, i.e., stock market booms, crashes, recoveries, recessions, and good and bad market situations. I take into account that the effect of realized market volatility on the trading behavior of US MFs may not be linear and can be higher during certain periods. Using returns and the volatility of the S\&P 500 Index as a proxy for market returns and realized volatility, I segregate the realized quarterly volatility into ten deciles in order to investigate the general herding-volatility relationship. I also explore the herding behavior of MFs in particular cases, i.e., Black Monday (1987), the dotcom bubble (2000), the credit crisis (2007), and good and bad market conditions. To differentiate between good and bad market conditions, I sort the returns and the volatility of the S\&P 500 Index into five quintiles and match them in reverse order to construct five portfolios. The extreme quintiles (the lower quintile of returns with the upper quintile of volatility and vice versa) are supposed to be crisis and boom periods, respectively. I define a market situation as bad (good) if it falls contemporaneously into the second (fourth) quintile of market returns and the fourth (second) quintile of market realized volatility. Last, the middle quintile is defined as a normal period.

Grinblatt et al. (1995) document that average herding varies across different styles of MFs. For instance, they find higher herding in growth funds and lower herding in balanced funds, which means that herding across MFs' styles may vary over time, i.e., over time, some MFs may herd more than others. I also investigate the anomaly of the small-firm effect in the trading behavior of MFs.

\section{Empirical Results}

\subsection{Does Herding Increase Over Time?}

I begin my analysis by computing the LSV herding measure over the analysis period; Table 1 shows the results of our LSV herding measures over time. In Panel A of Table 1, I observe a slightly higher level of average overall herding, approximately $5.75 \%$, compared with prior studies on US MFs. Economically, this number translates as follows: if 100 MFs are active in the same security in the same month, then 5.75 more MFs are trading on the same side of the market than would be expected under the null hypothesis of random selection of securities. The LSV herding measures are averaged over time and securities; Panel B and C in Table 1 further highlight that herding levels consistently increase 
even at five-year and ten-year time spans. The overall average herding measure is characterized by sell-herding, i.e., sell-herding is stronger than buy-herding, which is consistent with Grinblatt et al. (1995) but inconsistent with the findings of Wylie (2005).

Table 1. Mutual Funds' herding over time

\begin{tabular}{|c|c|c|c|}
\hline Panel A & Overall & Buy & Sell \\
\hline \multirow[t]{2}{*}{ Overall (1980-2009) } & 5.748 & 4.836 & 7.383 \\
\hline & $(0.020)$ & $(0.017)$ & $(0.046)$ \\
\hline Panel B & 5-years & & \\
\hline \multirow[t]{2}{*}{$1980-1985$} & 4.333 & 2.480 & 6.960 \\
\hline & $(0.071)$ & $(0.055)$ & $(0.150)$ \\
\hline \multirow[t]{2}{*}{$1986-1990$} & 4.873 & 3.684 & 6.432 \\
\hline & $(0.056)$ & $(0.049)$ & $(0.112)$ \\
\hline \multirow[t]{2}{*}{ 1991-1995 } & 5.408 & 3.720 & 8.320 \\
\hline & $(0.043)$ & $(0.033)$ & $(0.099)$ \\
\hline \multirow[t]{2}{*}{$1996-2000$} & 5.654 & 3.880 & 8.792 \\
\hline & $(0.044)$ & $(0.032)$ & $(0.104)$ \\
\hline \multirow[t]{2}{*}{ 2001-2005 } & 6.349 & 6.170 & 6.795 \\
\hline & $(0.041)$ & $(0.036)$ & $(0.114)$ \\
\hline \multirow[t]{2}{*}{ 2006-2009 } & 7.407 & 7.781 & 6.682 \\
\hline & $(0.057)$ & $(0.057)$ & $(0.126)$ \\
\hline Panel C & 10-year: & & \\
\hline \multirow[t]{2}{*}{ 1980-1990 } & 4.660 & 3.199 & 6.635 \\
\hline & $(0.044)$ & $(0.037)$ & $(0.090)$ \\
\hline \multirow[t]{2}{*}{ 1991-2000 } & 5.528 & 3.799 & 8.550 \\
\hline & $(0.030)$ & $(0.023)$ & $(0.072)$ \\
\hline \multirow[t]{2}{*}{ 2001-2009 } & 6.755 & 6.861 & 6.513 \\
\hline & $(0.032)$ & $(0.030)$ & $(0.079)$ \\
\hline
\end{tabular}

Notes: Table 1 reports the results of the LSV herding measures at the overall, buy and sell sub-group levels. Overall, buy and sell herding measures are presented for different time periods. The results are in percentages, standard errors are in parentheses and the T-tests are two-tailed. All results are statistically significant at $1 \%$ level.

Source: Thomson Financial/CDA-Spectrum

I observe that in general, average herding in later time periods is on average higher than herding in earlier time periods. More importantly, the rate of increase is higher during more recent periods. A significantly positive effect of time on the LSV herding measure tends to support the hypothesis of increased herding over time in the investment behavior of US MFs. This observation leads us to explore the determinants of increased herding in MFs' long term investment behavior; therefore, I focus on funds' expertise in true information extraction through experienced trading, MFs' characteristics (style, size) (Note 5), increased participation of MFs in the funds industry and market realized volatility as some of the potential factors driving increased levels of herding in MFs' long term investment behavior. The longer the time horizon of the investment operations of a mutual fund, the more investment experience the mutual fund managers attain and, in turn, the higher the expected herding because different experienced MF managers are expected to make the same decisions at the same time by inferring the same information from the signals from the same security. Due to the non-availability of the data, I leave this issue for future research.

Grinblatt et al. (1995) document slightly different levels of herding across MFs' styles. I extend our analysis to investigate whether funds' styles explain increased average herding over time. Following Grinblatt et al. (1995), I first attempt to calculate whether herding levels are significantly different across MFs' classifications, and then I extend our 
investigation to explore whether the herding contributions of some of these styles to the overall herding over time is higher compared with other styles. The results for the average LSV herding measures for each style are presented in Panel A of Table 2.

Table 2. Mutual Funds' herding across different styles

\begin{tabular}{cccccc}
\hline Panel A & $\begin{array}{c}\text { Aggressive } \\
\text { Growth }\end{array}$ & Growth & $\begin{array}{c}\text { Growth \& } \\
\text { Income }\end{array}$ & Balanced & Unclassified \\
\hline overall herding & 4.304 & 5.208 & 5.817 & 6.707 & 9.775 \\
& $(0.692)$ & $(0.023)$ & $(0.037)$ & $(0.043)$ & $(0.047)$ \\
buy herding & -1.532 & 4.284 & 5.184 & 5.297 & 6.634 \\
sell herding & $(0.421)$ & $(0.021)$ & $(0.036)$ & $(0.042)$ & $(0.035)$ \\
& 16.145 & 6.56 & 6.855 & 8.723 & 16.017 \\
Panel B & $(1.72)$ & $(0.047)$ & $(0.078)$ & $(0.085)$ & $(0.115)$ \\
Beta & 0.137 & 0.595 & 0.284 & 0.089 & 0.173 \\
R2 & 0.0434 & 0.409 & 0.178 & 0.036 & 0.234 \\
Adj. R2 & 0.0354 & 0.404 & 0.172 & 0.028 & 0.226 \\
\hline
\end{tabular}

Notes: Table 2 reports the results of the LSV average herding measures at the overall, buy and sell sub-group levels for different styles of US mutual funds. Overall, buy and sell average herding measures are presented for different styles of MFs classified based on their objective codes. Panel A shows the average herding across different styles and the results are in percentages. Panel B exhibits the regression results of average quarterly herding of each style of MFs on overall quarterly average herding levels. Standard errors are in parentheses and T-tests are two-tailed. Three asterisks indicate statistical significance at the $1 \%$ level.

Source: Thomson Financial/CDA-Spectrum

I find that herding level differs significantly across different styles of MFs classified on the basis of their objective codes. I find aggressive growth MFs experience the minimum and unclassified MFs bear the maximum average herding levels. Though unclassified MFs' trading exposes the highest average herding levels across different styles of the MFs, the growth and growth \& income MFs are dominant in terms of market capitalization and numbers in our data. This observation leads us to investigate the amount each group contributes to the overall average herding. I calculate quarterly herding across mutual fund styles and regress it using overall quarterly average herding as the dependent variable. The results are illustrated in Panel B of Table 2. I observe that though unclassified MFs herd most, growth MFs lead. Balanced MFs are the least in terms of effect and explanation for overall herding. The results also show that the investment behavior of the growth MFs appears to be the major driver of increased herding over time in US MFs' investment behavior.

Prior studies document the diseconomies of scale Perold and Salomon Jr (1991) concerning the trading costs of US MFs, yet, in absolute terms, large MFs bear more trading costs (Note 6) compared with small MFs. Funds with low capitalizations may require greater search costs to explore desirable securities for their portfolios. Because firm size proxies the amount of information and the number of professional analysts that process the available information about an enterprise Collins, Kothari, and Rayburn (1987), the size of a MF has the potential to affect herding in the sense that a large mutual fund has the ability to bear a higher absolute cost for information collection and security analysis. A large MF can hire smart managers for this purpose; if some of the large funds' smart managers pick up the same security for analysis at the same time, they may infer the same signals on the basis of their expert information. Thus, on one hand, inferring the same information may induce large MFs to trade the same security at the same time and in the same direction; on the other hand, small MFs may mimic the profitable strategies of the large funds to reduce their cost of information collection and thus cause a higher LSV herding measure. To investigate the validity of this theory, I sort all the MFs into ten deciles each quarter on the basis of their quarterly equity holdings and calculate their LSV herding measures. Table 3 presents the average LSV herding results for each decile. Though insignificant values of the F-test do not support convincing evidence for this theory, there is weak evidence against it when I move from the lowest size decile to the highest size decile. In fact, I observe significant herding in all deciles; however, the average herding measure does not change significantly across all deciles. I find comparatively higher levels of herding in extreme deciles (and significant values of the F-test show that average herding changes across deciles). The comparatively 
higher levels of herding in smaller-sized MFs can be attributed to the fact that small MFs mimic the trading strategies of large MFs, while the comparatively high levels of herding in higher deciles may be information-based. I also run a regression of the size-decile herding on overall herding to explore whether particular size-deciles explain most of the overall herding. Panel B of Table 3 presents the regression results; it is clear that higher-size deciles affect the overall herding most. A higher $\mathrm{R}^{2}$ for large MFs indicates that the herding behavior of large MFs explains most of the overall average quarterly herding. I also find herding asymmetry across the fund-size deciles' herding, with large MFs herding more on the buy side and small MFs herding more on the sell side.

Table 3. Mutual Funds' herding across fund-size deciles

\begin{tabular}{lcccccccccc}
\hline Panel A & Lowest & $\mathbf{2}$ & $\mathbf{3}$ & $\mathbf{4}$ & $\mathbf{5}$ & $\mathbf{6}$ & $\mathbf{7}$ & $\mathbf{8}$ & $\mathbf{9}$ & Highest \\
\hline Overall & 5.685 & 4.917 & 5.743 & 4.738 & 4.859 & 5.731 & 4.907 & 5.285 & 5.361 & 5.57 \\
& $(0.035)$ & $(0.033)$ & $(0.034)$ & $(0.032)$ & $(0.032)$ & $(0.033)$ & $(0.032)$ & $(0.033)$ & $(0.032)$ & $(0.033)$ \\
Buy & 2.833 & 2.557 & 3.552 & 2.675 & 3.159 & 3.448 & 3.045 & 3.335 & 3.812 & 3.639 \\
& $(0.026)$ & $(0.025)$ & $(0.027)$ & $(0.027)$ & $(0.026)$ & $(0.026)$ & $(0.026)$ & $(0.027)$ & $(0.028)$ & $(0.026)$ \\
sell & 10.498 & 8.998 & 9.154 & 7.889 & 7.472 & 9.242 & 7.787 & 8.182 & 7.613 & 8.611 \\
& $(0.081)$ & $(0.076)$ & $(0.074)$ & $(0.069)$ & $(0.068)$ & $(0.071)$ & $(0.069)$ & $(0.07)$ & $(0.066)$ & $(0.072)$ \\
Panel B & & \multicolumn{7}{c}{ Regression results of fund-size herding on overall herding } & & \\
coeff. & 0.166 & 0.232 & 0.14 & 0.165 & 0.094 & 0.155 & 0.252 & 0.231 & 0.27 & 0.171 \\
R2 & 0.088 & 0.127 & 0.076 & 0.076 & 0.032 & 0.103 & 0.184 & 0.157 & 0.236 & 0.136 \\
Adj. R2 & 0.08 & 0.12 & 0.068 & 0.068 & 0.024 & 0.095 & 0.178 & 0.15 & 0.229 & 0.129 \\
\hline
\end{tabular}

Notes: Table 3 reports the results of the LSV herding measures at the overall, buy and sell sub-group levels. In Panel A, overall, buy and sell herding measures are presented for fund-size deciles, where deciles are created on the basis of the quarterly total assets each mutual fund holds. The first decile shows the minimum/lowest $10 \%$, and the last decile presents the upper $10 \%$ of funds' capitalizations. Panel B exhibits the regression results of the average quarterly herding for each decile of MF sizes on the overall quarterly average herding levels. Panel A's results are in percentages, standard errors are in parentheses and the T-tests are two-tailed. All results are significant at the $1 \%$ level.

Source: Thomson Financial/CDA-Spectrum

4.2 Do Herds Emerge and Become Dominant in Times of High Price Movements?

Market volatility is observed to be non-constant and varying over time (Campbell (2001), and some studies Choe et al. (1999); (Patterson \& Sharma, 2004) implicitly indicate a possible relationship between market volatility and LSV herding measures. I also observe herding levels changing over time (see Table 1). This observation leads us to suspect that market volatility may affect the incentives for US MFs to herd. In an attempt to explore the empirical evidence for a relationship between stock market realized volatility and MFs' herding behavior, I classify quarterly market realized volatility into ten deciles and calculate herding for each decile. (Note 7) The results are documented in Table 4. I observe unclear patterns of LSV herding across the volatility deciles; however, average herding in the upper deciles of market realized volatilities is slightly higher than in the lower deciles. I also observe a dominating pattern, in general, for sell-herding over buy-herding in the higher volatility deciles. In general, our results are inconsistent with studies Choe et al. (1999); (Lobao \& Serra, 2007) that document that herding decreases in bad market periods. Our results are also inconsistent with Hwang and Salmon (2004), who find reduced herding during the Asian and Russian crises, and Christie and Huang (1995), who do not find significant herding during down markets. However, higher buy-herding during down market periods and higher sell-herding during market downturns is consistent with the findings of Choe et al. (1999). 
Table 4. Mutual Funds' herding across realized market volatility deciles

\begin{tabular}{lcccccccccc}
\hline Herding & lowest & 2 & 3 & 4 & 5 & 6 & 7 & 8 & 9 & Highest \\
\hline Overall & 5.62 & 5.952 & 6.605 & 6.039 & 5.354 & 5.161 & 6.014 & 5.703 & 7.359 & 5.803 \\
& $(0.071)$ & $(0.071)$ & $(0.077)$ & $(0.072)$ & $(0.078)$ & $(0.073)$ & $(0.077)$ & $(0.074)$ & $(0.082)$ & $(0.082)$ \\
Buy & 6.333 & 6.011 & 5.717 & 5.023 & 4.564 & 4.421 & 5.494 & 3.912 & 6.059 & 5.043 \\
& $(0.07)$ & $(0.064)$ & $(0.067)$ & $(0.062)$ & $(0.069)$ & $(0.059)$ & $(0.069)$ & $(0.052)$ & $(0.071)$ & $(0.071)$ \\
Sell & 4.06 & 5.797 & 8.277 & 7.785 & 6.506 & 6.629 & 6.858 & 8.917 & 9.528 & 7.117 \\
& $(0.166)$ & $(0.194)$ & $(0.182)$ & $(0.164)$ & $(0.161)$ & $(0.182)$ & $(0.168)$ & $(0.179)$ & $(0.183)$ & $(0.186)$ \\
\hline
\end{tabular}

Notes: Table 4 reports the results of the LSV herding measures at the overall, buy and sell sub-group levels. Overall, buy and sell herding measures are presented for stock market volatility deciles where the deciles are constructed by sorting the quarterly stock market volatility, proxied by the volatility of the S\&P 500 Index, into ten equal parts over the observation period. The first decile shows the lowest $10 \%$, and the last decile presents the upper $10 \%$ of the 120 quarterly market volatility observations. The results are in percentages, standard errors are in parentheses and the T-tests are two-tailed. All results are significant at the $1 \%$ level.

Source: Thomson Financial/CDA-Spectrum

Panel B of Table 1 also shows that the herding increment seems to be higher in time periods involving any crisis episode - see, for instance, the dates of Black Monday in 1987, the dotcom crisis (2000-2002) and the recent credit crisis (2007) - which suggests the possibility of a significant shift in MFs' trading behavior during these specific events. This observation leads us to investigate the herding patterns in investment behavior of US MFs during periods of market turmoil. The results presented in Panel B of Table 5 show significantly higher herding during periods of market turmoil than during non-turmoil periods. I further extend our analysis to investigate herding in US MFs' trading behavior during important crisis periods; Panel A of Table 5 reveals herding during the different crisis periods in our sample. Again, I observe a chronological increase in MFs' herding behavior. I observe that herding during the global credit crisis (2007) was much higher compared with other crisis periods. The major reason for this higher scale of herding during the credit crisis (2007) seems to be the dissemination of the crisis to all types of stocks, while a comparatively low level of herding during the Black Monday crisis (1987) is a result of crisis exposure that was mainly limited to certain stock indices. I also investigate the herding behavior of US MFs in good and bad market conditions (as defined above) and observe much higher levels of herding during bad environments compared with good market conditions. I find herding levels in bad market conditions to be at least 2 percent higher than in good environments. However, this higher level of herding is mainly characterized by sell-herding. Higher buy-herding levels than sell-herding levels in bad market conditions is inconsistent with the findings of Choe et al. (1999).

Table 5. Average herding by stock market conditions

\begin{tabular}{|c|c|c|c|}
\hline Panel A. By crisis & Overall & Buy & Sell \\
\hline \multirow[t]{2}{*}{ Black Monday Oct 1987-Dec 1988} & 3.216 & 3.929 & 2.403 \\
\hline & $(0.199)$ & $(0.195)$ & $(0.362)$ \\
\hline \multirow[t]{2}{*}{ Dotcom Bubble Mar 2000-Oct 2002} & 6.219 & 4.985 & 8.693 \\
\hline & $(0.055)$ & $(0.041)$ & $(0.141)$ \\
\hline \multirow[t]{3}{*}{ Credit Crisis Sep 2007- Dec 2009} & 7.407 & 7.781 & 6.682 \\
\hline & $(0.057)$ & $(0.057)$ & $(0.126)$ \\
\hline & \multicolumn{3}{|c|}{ Panel B. Crisis vs. Non-crisis } \\
\hline \multirow[t]{2}{*}{ During crisis (overall) } & 6.643 & 6.283 & 7.333 \\
\hline & $(0.039)$ & $(0.035$ & $(0.092)$ \\
\hline \multirow[t]{3}{*}{ During non-crisis (overall) } & 5.433 & 4.310 & 7.399 \\
\hline & $(0.023)$ & $(0.019)$ & $(0.053)$ \\
\hline & Market & & \\
\hline \multirow[t]{2}{*}{ Bad Market Periods } & 8.069 & 8.089 & 8.024 \\
\hline & $(0.140)$ & $(0.125)$ & $(0.362)$ \\
\hline \multirow[t]{2}{*}{ Good Market Periods } & 5.923 & 4.185 & 8.444 \\
\hline & $(0.148)$ & $(0.118)$ & $(0.316)$ \\
\hline
\end{tabular}

Notes: Table 5 reports the results of the LSV herding measures at the overall, buy and sell sub-group levels. Overall, buy and sell herding measures are presented for different time environments of the market. Crises are important historical stock market crashes. Bear and bull market conditions are constructed on the basis of returns and volatility quintiles (5) of the S\&P 500 Index. The results are in percentages, standard errors are in parentheses and the T-tests are two-tailed. All results are statistically significant at the $1 \%$ level.

Source: Thomson Financial/CDA-Spectrum 


\subsection{Does MFs' Demand for Stock Hinge on the Stock's Characteristics?}

Over time, increased participation of MFs in the financial markets and their trading of an increasing number of securities has been observed (see Appendix A and Figure 1), which implies that when more MFs trade in the stock market, they investigate and trade more stocks. Increased active trading or increased participation of MFs in the security market may decrease the chances of higher herding in some of the traded securities and, similarly, a higher number of available securities to trade may hamper the concentration of MFs in certain stocks because they have more choices among available securities to include in their portfolios. To investigate whether increased participation of MFs in the financial markets affects their herding levels, I sort the number of quarterly traded securities, a proxy for increased participation of MFs, over time into ten deciles and calculate the LSV herding measure for each of the deciles; the results are shown in Table 6. To our surprise, I find increased levels of herding in general, though non-monotonic, as I move from the lower decile of the number of securities to the higher decile.

Table 6. Mutual Funds' herding across security-count deciles

\begin{tabular}{|c|c|c|c|c|c|c|c|c|c|c|}
\hline Herding & lowest & 2 & 3 & 4 & 5 & 6 & 7 & 8 & 9 & Highest \\
\hline \multirow[t]{2}{*}{ Overall } & 3.946 & 4.06 & 4.657 & 3.949 & 6.467 & 6.921 & 6.519 & 7.023 & 6.804 & 5.53 \\
\hline & $(0.182)$ & $(0.181)$ & $(0.184)$ & $(0.187)$ & $(0.194)$ & $(0.178)$ & $(0.189)$ & $(0.177)$ & $(0.194)$ & (0.192) \\
\hline \multirow[t]{2}{*}{ Buy } & 2.204 & 1.681 & 2.157 & 2.448 & 4.734 & 4.734 & 4.155 & 4.016 & 3.088 & 1.538 \\
\hline & $(0.124)$ & $(0.114)$ & $(0.121)$ & $(0.128)$ & $(0.149)$ & $(0.125)$ & $(0.126)$ & $(0.11)$ & $(0.12)$ & $(0.096)$ \\
\hline \multirow[t]{2}{*}{ Sell } & 6.629 & 8.035 & 8.251 & 5.946 & 9.92 & 12.053 & 11.63 & 14.059 & 15.634 & 17.654 \\
\hline & $(0.417)$ & $(0.433)$ & $(0.403)$ & $(0.398)$ & $(0.49)$ & $(0.5)$ & $(0.512)$ & $(0.498)$ & $(0.536)$ & $(0.623)$ \\
\hline
\end{tabular}

Notes: Table 6 reports the results of the LSV herding measures at the overall, buy and sell sub-group levels. Overall, buy and sell herding measures are presented for the number of traded securities per quarter by sorting them into 10 deciles. The first decile shows the minimum $10 \%$ of the number of quarterly traded securities, and the last decile shows the maximum $10 \%$ of the number of quarterly traded securities. The results are in percentages, standard errors are in parentheses and the T-tests are two-tailed. All results are significant at the $1 \%$ level.

Source: Thomson Financial/CDA-Spectrum

Appendix A shows a high positive correlation between the number of MFs participating in the financial markets over time and the number of securities they trade. The presence of more tradable securities in the financial markets may hamper the concentration of US MFs in certain securities. Our results show that this is not the case; an increased number of listed securities in the financial markets over time does not affect the choices of MFs, and the MFs remain concentrated in certain stocks. Though the participation of MFs in the financial markets increases over time, their concentration converges on certain desired securities. It seems that new entrants follow the old ones in certain stocks, which eventually adds to the average overall herding levels over time. This finding raises another important question: is there a relationship between security characteristics and increased herding? To identify this link, I focus on risk and the stock-size preferences of the MFs for the concentrating characteristics of the securities. Taking share size, I sort all stocks into ten deciles each quarter and calculate the average LSV herding measure for each decile. The results are shown in Table 7. I find an asymmetric relationship between the average herding measure and the stock-size deciles. Panel A of Table 7 shows a nonlinear demand for stock-size deciles, i.e., the LSV herding measure increases as I move from the middle to the extremes of the stock-size deciles. High demand for large stocks is consistent with the findings of Gompers and Metrick (1998a), but the higher demand for smaller-sized stocks is inconsistent with the findings of Falkenstein (1996), who finds an increasing aversion of funds for low-priced holdings. The general results in Panel A of Table 7 show that US MFs have a much higher demand for stocks in the extreme deciles, especially at the lower end, but the results do not explain which share-size decile accounts for most of the overall herding over time. To address this issue, I run regressions of each share-size decile's herding on the overall herding; the results are presented in Panel B of Table 7. Our results further confirm that smaller-sized stocks affect and explain most of the overall quarterly average herding; thus, the small-firm effect exists. I further note a systematic increase (decrease) of buy- (sell-) herding as I move from the low (high) to the higher- (lower-) sized decile. This finding is consistent with (Gompers \& Metrick, 1998a) and Falkenstein (1996) in documenting that MFs focus more on holding large stocks. Our results may lead us to conclude that although US MFs' demand for large stocks increases over time, they herd most in lower-sized stocks. 
Table 7. Mutual Funds' herding across stock-size deciles

\begin{tabular}{lrrrrrrrrrr}
\hline Panel A & lowest & 2 & 3 & 4 & 5 & 6 & 7 & 8 & 9 & Highest \\
\hline Overall & 5.738 & 4.329 & 3.871 & 3.554 & 3.503 & 3.536 & 3.525 & 3.742 & 4.204 & 5.188 \\
& $(0.038)$ & $(0.04)$ & $(0.043)$ & $(0.044)$ & $(0.046)$ & $(0.05)$ & $(0.055)$ & $(0.061)$ & $(0.072)$ & $(0.085)$ \\
Buy & 2.217 & 2.689 & 2.864 & 2.874 & 3.24 & 3.292 & 3.472 & 3.952 & 4.558 & 5.791 \\
& $(0.025)$ & $(0.032)$ & $(0.037)$ & $(0.041)$ & $(0.044)$ & $(0.048)$ & $(0.054)$ & $(0.06)$ & $(0.072)$ & $(0.087)$ \\
Sell & 11.493 & 6.802 & 5.399 & 4.575 & 3.905 & 3.926 & 3.608 & 3.396 & 3.603 & 4.037 \\
& $(0.087)$ & $(0.087)$ & $(0.09)$ & $(0.092)$ & $(0.096)$ & $(0.103)$ & $(0.112)$ & $(0.127)$ & $(0.15)$ & $(0.182)$ \\
Panel B & & \multicolumn{7}{c}{ Regression results of stock-size herding on overall herding } & & \\
Coeff. & 0.703 & 0.842 & 0.994 & 1.053 & 0.925 & 0.852 & 0.714 & 0.656 & 0.545 & 0.641 \\
R2 & 0.726 & 0.576 & 0.448 & 0.557 & 0.397 & 0.355 & 0.323 & 0.302 & 0.282 & 0.442 \\
Adj. R2 & 0.723 & 0.572 & 0.444 & 0.553 & 0.392 & 0.349 & 0.318 & 0.296 & 0.276 & 0.437 \\
\hline
\end{tabular}

Notes: Table 7 reports the results of the LSV herding measures at the overall, buy and sell sub-group levels. In Panel A, overall, buy and sell herding measures are presented for stock-size (stock price) deciles, where the deciles are constructed by sorting the prices of traded securities into 10 deciles each quarter. The first decile shows the lowest $10 \%$, and the last decile shows the upper $10 \%$ of the stocks' prices each quarter. Panel B shows the regression results of the average quarterly herding of each decile of stock size on overall quarterly average herding levels. Panel A's results are in percentages, standard errors are in parentheses and the T-tests are two-tailed. All results are significant at the $1 \%$ level.

Source: Thomson Financial/CDA-Spectrum

I further investigate whether large MFs have the same demand for large stocks as small MFs. For this purpose, I sort all MFs into five quantiles each quarter and then resort each size quantile into five share-size quantiles. I calculate the quarterly average herding of each of the twenty-five quantiles each quarter; the results are shown in Table 8. Our results in Panel A of Table 8 show that the average LSV herding across size quantiles does not change much, but that in general, both large and small MFs herd the most in the lowest capitalization stocks. When I look at the differences between the buy and sell LSV herding measures, the measures decrease from the lowest stock-size quantile to the highest stock-size quantile; the difference decreases most rapidly in the highest fund-size quantile. This observation shows an increasing (decreasing) demand (aversion) for (to) large (small) stocks for all MFs; however, the largest MFs show the highest demand for and the lowest aversion to the largest stocks. In general, I find that MFs herd most in the smaller-sized stocks, but this herding is mainly characterized by the highest aversion to and the least demand for small stocks. Over time, all MFs demand more large stocks; however, this tendency is most prominent in the largest MFs. 
Table 8. LSV herding measures for share-size and fund-size quantiles

\begin{tabular}{|c|c|c|c|c|c|}
\hline \multirow{2}{*}{$\begin{array}{c}\text { Panel A } \\
\text { Share-Size } \\
\text { Quants }\end{array}$} & \multicolumn{5}{|c|}{$\begin{array}{l}\text { Overall Herding } \\
\text { Fund-Size Quants }\end{array}$} \\
\hline & Smallest & 2 & 3 & 4 & Largest \\
\hline \multirow[t]{2}{*}{ Smallest } & 4.503 & 4.668 & 4.589 & 4.526 & 5.269 \\
\hline & $(0.054)$ & $(0.052)$ & $(0.049)$ & $(0.050)$ & (0.049) \\
\hline \multirow[t]{2}{*}{2} & 3.609 & 3.632 & 3.770 & 3.585 & 3.872 \\
\hline & $(0.052)$ & $(0.051)$ & $(0.049)$ & $(0.049)$ & $(0.051)$ \\
\hline \multirow[t]{2}{*}{3} & 3.365 & 3.293 & 3.534 & 3.195 & 3.518 \\
\hline & $(0.054)$ & $(0.053)$ & $(0.052)$ & $(0.052)$ & $(0.053)$ \\
\hline \multirow[t]{2}{*}{4} & 3.537 & 3.317 & 3.435 & 3.119 & 3.511 \\
\hline & $(0.059)$ & $(0.059)$ & $(0.058)$ & $(0.058)$ & $(0.059)$ \\
\hline \multirow[t]{2}{*}{ Largest } & 4.129 & 3.780 & 3.895 & 3.506 & 4.081 \\
\hline & $(0.071)$ & $(0.070)$ & $(0.072)$ & $(0.070)$ & $(0.073)$ \\
\hline Panel B & \multicolumn{5}{|c|}{ Buy-Herding } \\
\hline \multirow[t]{2}{*}{ Smallest } & 0.373 & 1.135 & 1.236 & 1.202 & 1.796 \\
\hline & $(0.033)$ & $(0.036)$ & $(0.033)$ & $(0.034)$ & $(0.034)$ \\
\hline \multirow[t]{2}{*}{2} & 1.405 & 1.839 & 2.139 & 2.040 & 2.577 \\
\hline & $(0.040)$ & $(0.042)$ & $(0.041)$ & $(0.041)$ & $(0.043)$ \\
\hline \multirow[t]{2}{*}{3} & 1.991 & 2.204 & 2.565 & 2.336 & 2.943 \\
\hline & $(0.046)$ & $(0.048)$ & $(0.048)$ & $(0.048)$ & $(0.051)$ \\
\hline \multirow[t]{2}{*}{4} & 2.820 & 2.710 & 3.000 & 2.636 & 3.421 \\
\hline & $(0.055)$ & $(0.057)$ & $(0.056)$ & $(0.057)$ & $(0.061)$ \\
\hline \multirow[t]{2}{*}{ Largest } & 3.971 & 3.832 & 3.769 & 3.421 & 4.285 \\
\hline & $(0.071)$ & $(0.073)$ & $(0.073)$ & $(0.074)$ & $(0.078)$ \\
\hline Panel C & \multicolumn{5}{|c|}{ Sell-Herding } \\
\hline \multirow[t]{2}{*}{ Smallest } & 11.745 & 9.977 & 9.699 & 9.808 & 10.788 \\
\hline & $(0.126)$ & $(0.113)$ & $(0.108)$ & $(0.111)$ & (0.109) \\
\hline \multirow[t]{2}{*}{2} & 7.049 & 6.073 & 6.079 & 5.775 & 5.755 \\
\hline & $(0.114)$ & $(0.105)$ & (0.102) & $(0.103)$ & $(0.106)$ \\
\hline \multirow[t]{2}{*}{3} & 5.416 & 4.780 & 4.860 & 4.339 & 4.311 \\
\hline & $(0.113)$ & $(0.105)$ & $(0.105)$ & $(0.101)$ & $(0.105)$ \\
\hline \multirow[t]{2}{*}{4} & 4.592 & 4.156 & 4.068 & 3.763 & 3.632 \\
\hline & $(0.121)$ & $(0.116)$ & $(0.116)$ & $(0.110)$ & $(0.112)$ \\
\hline \multirow[t]{2}{*}{ Largest } & 4.378 & 3.710 & 4.079 & 3.623 & 3.805 \\
\hline & $(0.145)$ & $(0.136)$ & $(0.141)$ & $(0.132)$ & (0.134) \\
\hline
\end{tabular}

Notes: Table 8 reports the results of the LSV herding measures at the overall, buy and sell sub-group levels. Overall, buy and sell herding measures are presented for stocks' betas in combination with fund size. The beta for each stock traded by US MFs has been calculated using EVENTUS, which uses the CRSP database to find stocks' betas. After calculating the quarterly betas of the stocks, they are sorted into five quantiles each quarter. The quantile with the smallest $20 \%$ of betas is called the lowest quant and the quantile with the largest $20 \%$ of betas is called the highest quant. A similar distribution has been made for the fund size. The results are in percentages, standard errors are in parentheses and the T-tests are two-tailed. All results are statistically significant at the $1 \%$ level.

Source: Thomson Financial/CDA-Spectrum 
I also investigate if increased herding over time in the trading behavior of US MFs is due to a change in their risk preferences over time; therefore, I calculate stocks' betas for each of the holdings of MFs over the sample period using the CRSP database, and then I sort the stocks' betas into ten deciles. I repeat this process each quarter; the results of the LSV herding measure for all ten deciles, averaged over time and securities, are shown in Panel A of Table 9. Our results strongly endorse the idea that US MFs herd most in low-beta stocks. Furthermore, their herding increases (though not monotonically) as I move from the higher to the lower-beta stocks. The noticeable result is that the difference between buy and sell-herding decreases in beta, i.e., over time US MFs herd more into (out of) the higher(lower-) beta stocks. In other words, US MFs converge on the high-beta stocks in the long term. This observation shows that US MFs have some preferences for low-beta stocks in their long-term trading behavior. They herd more in the stocks that do not change as much with the market. Panel B of Table 9 shows the regression results of each beta decile's quarterly herding on the overall average herding. The results further support the hypothesis that over time US MFs are more inclined toward stocks that have little correlation with market conditions. In other words, in the long term, the lowest-beta stocks attract the most MFs, but this result is mainly driven by herding out of these stocks.

Table 9. Mutual Funds' herding across stocks' beta deciles

\begin{tabular}{lrrrrrrrrrr}
\hline Panel A & lowest & 2 & 3 & 4 & 5 & 6 & 7 & 8 & 9 & highest \\
\hline Overall & 6.053 & 5.058 & 4.817 & 4.638 & 4.602 & 4.573 & 4.515 & 4.559 & 4.685 & 5.337 \\
& $(0.048)$ & $(0.049)$ & $(0.049)$ & $(0.048)$ & $(0.048)$ & $(0.047)$ & $(0.045)$ & $(0.045)$ & $(0.045)$ & $(0.048)$ \\
Buy & 4.930 & 4.335 & 4.195 & 4.158 & 4.253 & 4.268 & 4.359 & 4.429 & 4.675 & 5.300 \\
& $(0.040)$ & $(0.045)$ & $(0.046)$ & $(0.046)$ & $(0.047)$ & $(0.046)$ & $(0.045)$ & $(0.044)$ & $(0.044)$ & $(0.044)$ \\
Sell & 8.007 & 6.166 & 5.740 & 5.367 & 5.125 & 5.055 & 4.770 & 4.783 & 4.703 & 5.415 \\
& $(0.109)$ & $(0.103)$ & $(0.101)$ & $(0.098)$ & $(0.097)$ & $(0.098)$ & $(0.095)$ & $(0.097)$ & $(0.101)$ & $(0.117)$ \\
Panel B & & \multicolumn{7}{c}{ Regression results of stocks' beta-herding on overall herding } & & \\
coeff. & 0.737 & 0.874 & 0.900 & 0.967 & 0.937 & 0.988 & 0.929 & 0.822 & 0.823 & 0.686 \\
R2 & 0.816 & 0.731 & 0.659 & 0.538 & 0.503 & 0.549 & 0.517 & 0.449 & 0.409 & 0.443 \\
Adj. R2 & 0.814 & 0.729 & 0.656 & 0.534 & 0.499 & 0.545 & 0.513 & 0.444 & 0.404 & 0.438 \\
\hline
\end{tabular}

Notes: Table 9 reports the results of the LSV herding measures at the overall, buy and sell sub-group levels. In Panel A, overall, buy and sell herding measures are presented for 10 deciles of stocks' betas, where the deciles are constructed by sorting all stocks' betas into 10 deciles each quarter. The first decile shows the lowest $10 \%$, and the last decile shows the upper $10 \%$ of the stocks' betas each quarter. Panel B shows the regression results of the average quarterly herding of each decile of stock's beta on the overall quarterly average herding levels. Panel A's results are in percentages, standard errors are in parentheses and the T-tests are two-tailed. All results are significant at the $1 \%$ level.

Source: Thomson Financial/CDA-Spectrum

In an attempt to explore whether the demand across stocks' riskiness changes with fund size, I first sort all the sampled MFs into five size quantiles, and then I sort each size quantile further into five beta quantiles. I repeat this process each quarter and then calculate the herding measures for each of the 25 sub-groups. The results are presented in Table 10. Consistent with the findings from Table 9, all types of MFs show the highest herding in the lowest-beta stocks; however, the demand for the lowest-beta stocks is the highest in the largest fund-size quantile. From Panel A of Table 10, we observe that all fund-size quantiles have a tendency to herd most in the lowest-beta quantile; however, the difference in average overall herding between the largest and the smallest beta quantiles is highest for the largest size quantile. Panel B and C of Table 10suggest that the largest MFs herd most when buying the largest beta stocks. This finding endorses our hypothesis that large MFs hire sophisticated asset managers who end up trading the same securities at the same time in the same direction after their evaluations. 
Table 10. LSV herding measure for fund-size and beta quantiles

\begin{tabular}{|c|c|c|c|c|c|}
\hline \multirow{2}{*}{$\begin{array}{c}\text { Panel A } \\
\text { Fund-size } \\
\text { Quants }\end{array}$} & \multicolumn{5}{|c|}{$\begin{array}{l}\text { Overall Herding } \\
\text { Beta Quants }\end{array}$} \\
\hline & Smallest & 2 & 3 & 4 & Largest \\
\hline Smallest & $\begin{array}{c}6.179 \\
(0.086)\end{array}$ & $\begin{array}{c}5.865 \\
(0.085)\end{array}$ & $\begin{array}{c}6.000 \\
(0.085)\end{array}$ & $\begin{array}{c}5.673 \\
(0.083)\end{array}$ & $\begin{array}{c}5.500 \\
(0.081)\end{array}$ \\
\hline 2 & $\begin{array}{c}6.356 \\
(0.084)\end{array}$ & $\begin{array}{c}6.086 \\
(0.083)\end{array}$ & $\begin{array}{c}5.826 \\
(0.081)\end{array}$ & $\begin{array}{c}5.790 \\
(0.080)\end{array}$ & $\begin{array}{c}5.527 \\
(0.079)\end{array}$ \\
\hline 3 & $\begin{array}{c}6.906 \\
(0.081)\end{array}$ & $\begin{array}{c}6.365 \\
(0.083)\end{array}$ & $\begin{array}{c}6.183 \\
(0.081)\end{array}$ & $\begin{array}{c}6.073 \\
(0.080)\end{array}$ & $\begin{array}{c}5.968 \\
(0.080)\end{array}$ \\
\hline 4 & $\begin{array}{c}6.226 \\
(0.080)\end{array}$ & $\begin{array}{c}6.060 \\
(0.081)\end{array}$ & $\begin{array}{c}5.873 \\
(0.080)\end{array}$ & $\begin{array}{c}5.656 \\
(0.078)\end{array}$ & $\begin{array}{c}5.606 \\
(0.077)\end{array}$ \\
\hline Largest & $\begin{array}{c}7.234 \\
(0.077)\end{array}$ & $\begin{array}{c}6.376 \\
(0.080)\end{array}$ & $\begin{array}{c}6.308 \\
(0.079)\end{array}$ & $\begin{array}{c}6.220 \\
(0.078)\end{array}$ & $\begin{array}{c}6.227 \\
(0.079)\end{array}$ \\
\hline Panel B & \multicolumn{5}{|c|}{ Buy-Herding } \\
\hline Smallest & $\begin{array}{c}2.293 \\
(0.057)\end{array}$ & $\begin{array}{c}2.810 \\
(0.061)\end{array}$ & $\begin{array}{c}3.150 \\
(0.063)\end{array}$ & $\begin{array}{c}2.785 \\
(0.062)\end{array}$ & $\begin{array}{c}2.654 \\
(0.060)\end{array}$ \\
\hline 2 & $\begin{array}{c}3.330 \\
(0.060)\end{array}$ & $\begin{array}{c}3.529 \\
(0.064)\end{array}$ & $\begin{array}{c}3.608 \\
(0.065)\end{array}$ & $\begin{array}{c}3.664 \\
(0.064)\end{array}$ & $\begin{array}{c}3.368 \\
(0.064)\end{array}$ \\
\hline 3 & $\begin{array}{c}3.466 \\
(0.058)\end{array}$ & $\begin{array}{c}3.570 \\
(0.062)\end{array}$ & $\begin{array}{c}3.736 \\
(0.064)\end{array}$ & $\begin{array}{c}3.727 \\
(0.063)\end{array}$ & $\begin{array}{r}3.800 \\
(0.063)\end{array}$ \\
\hline 4 & $\begin{array}{c}3.262 \\
(0.057)\end{array}$ & $\begin{array}{c}3.446 \\
(0.063)\end{array}$ & $\begin{array}{c}3.606 \\
(0.063)\end{array}$ & $\begin{array}{c}3.471 \\
(0.062)\end{array}$ & $\begin{array}{l}3.595 \\
(0.063)\end{array}$ \\
\hline Largest & $\begin{array}{c}4.363 \\
(0.059)\end{array}$ & $\begin{array}{c}4.221 \\
(0.065)\end{array}$ & $\begin{array}{c}4.485 \\
(0.066)\end{array}$ & $\begin{array}{c}4.496 \\
(0.067)\end{array}$ & $\begin{array}{r}4.456 \\
(0.067)\end{array}$ \\
\hline Panel C & \multicolumn{5}{|c|}{ Sell-Herding } \\
\hline Smallest & $\begin{array}{l}13.531 \\
(0.210)\end{array}$ & $\begin{array}{l}11.044 \\
(0.194)\end{array}$ & $\begin{array}{l}10.749 \\
(0.192)\end{array}$ & $\begin{array}{l}10.392 \\
(0.187)\end{array}$ & $\begin{array}{l}10.074 \\
(0.181)\end{array}$ \\
\hline 2 & $\begin{array}{l}11.272 \\
(0.190)\end{array}$ & $\begin{array}{c}9.967 \\
(0.180)\end{array}$ & $\begin{array}{c}9.208 \\
(0.176)\end{array}$ & $\begin{array}{c}8.924 \\
(0.171)\end{array}$ & $\begin{array}{c}8.743 \\
(0.168)\end{array}$ \\
\hline 3 & $\begin{array}{l}12.541 \\
(0.183)\end{array}$ & $\begin{array}{l}10.559 \\
(0.180)\end{array}$ & $\begin{array}{c}9.809 \\
(0.173)\end{array}$ & $\begin{array}{c}9.562 \\
(0.172)\end{array}$ & $\begin{array}{c}9.123 \\
(0.170)\end{array}$ \\
\hline 4 & $\begin{array}{c}11.251 \\
(0.185)\end{array}$ & $\begin{array}{l}10.078 \\
(0.175)\end{array}$ & $\begin{array}{c}9.309 \\
(0.172)\end{array}$ & $\begin{array}{c}9.001 \\
(0.169)\end{array}$ & $\begin{array}{c}8.633 \\
(0.164)\end{array}$ \\
\hline Largest & $\begin{array}{l}12.059 \\
(0.173)\end{array}$ & $\begin{array}{c}9.718 \\
(0.174)\end{array}$ & $\begin{array}{l}9.053 \\
(0.168)\end{array}$ & $\begin{array}{c}8.783 \\
(0.164)\end{array}$ & $\begin{array}{c}8.859 \\
(0.166)\end{array}$ \\
\hline
\end{tabular}

Notes: Table 10 reports the results of the LSV herding measures at the overall, buy and sell sub-group levels. Overall, buy and sell herding measures are presented for stocks' betas in combination with fund size. The beta for each stock traded by US MFs has been calculated using EVENTUS, which uses the CRSP database to find stocks' betas. Quarterly betas of the stocks are sorted into five quantiles each quarter. The quantile with the smallest $20 \%$ of betas is called the lowest quant, and the quantile with the largest $20 \%$ of betas is called the highest quant. Similar distributions have been made for the fund sizes. The results are in percentages, standard errors are in parentheses and the T-tests are two-tailed. All results are statistically significant at the $1 \%$ level.

Source: Thomson Financial/CDA-Spectrum

Our study also investigates MFs' herding behavior in interaction with market conditions and stocks' betas. Table 11 shows the summary results of MFs' herding for the lowest and the highest stock-beta quants under different market conditions. Panel A of Table 11 shows that overall herding does not change much for negative- and positive-beta stocks, but the demand (aversion) for (to) positive- (negative-) beta stocks is significantly higher (lower) than the negative-beta stocks over the course of investigation. Panel B of Table 11 presents the herding in different stock-beta 
quants vis-à-vis market conditions. I find that US mutual funds herd slightly more in positive-beta stocks during bull markets, which are mainly characterized by herding in the highest-beta stocks. Furthermore, average herding is slightly higher for the highest-beta quants in bear markets. Panel C of Table 11 shows that the average herding in crisis periods is significantly higher for both the lowest- and the highest-beta quants compared to non-crisis periods; however, this higher herding during crisis periods seems to be driven by a higher demand (aversion) for (to) high- (low-) beta stocks. I further explore whether this pattern is systemic during all the crisis periods individually. Our findings in Panel D of Table 11 show that overall average herding in the lowest-beta stocks is largely characterized by buy-herding during the global credit crisis and sell-herding during the dotcom crisis; however, overall herding in the highest-beta stocks is mainly characterized by both buy- and sell-herding during the dotcom crisis.

Table 11. Herding and Mutual Funds' Risk Preferences

\begin{tabular}{|c|c|c|c|c|c|c|}
\hline Herding & Overall & Buy & Sell & Overall & Buy & Sell \\
\hline \multirow[t]{3}{*}{ Panel A } & \multicolumn{3}{|c|}{ Negative Stocks' Beta } & \multicolumn{3}{|c|}{ Positive Stocks' Beta } \\
\hline & 4.471 & -0.012 & 14.115 & 4.059 & 1.722 & 8.321 \\
\hline & $(0.091)$ & $(0.072)$ & $(0.210)$ & $(0.022)$ & $(0.020)$ & $(0.048)$ \\
\hline Panel B: Beta Quant & \multicolumn{3}{|c|}{ Bear Markets } & \multicolumn{3}{|c|}{ Bull Markets } \\
\hline \multirow[t]{2}{*}{ Lowest } & 3.923 & 1.351 & 10.175 & 3.827 & 1.274 & 10.538 \\
\hline & $(0.336)$ & $(0.295)$ & $(0.839)$ & $(0.263)$ & $(0.236)$ & $(0.676)$ \\
\hline \multirow[t]{2}{*}{ Highest } & 5.172 & 4.257 & 7.364 & 4.737 & 3.092 & 8.627 \\
\hline & $(0.443)$ & $(0.404)$ & $(1.139)$ & $(0.320)$ & $(0.306)$ & $(0.772)$ \\
\hline \multirow[t]{2}{*}{ Negative Beta } & 3.631 & 1.101 & 11.679 & -3.670 & -0.011 & 14.066 \\
\hline & $(0.607)$ & $(0.501)$ & $(1.805)$ & $(0.423)$ & $(0.348)$ & (1.114) \\
\hline \multirow[t]{2}{*}{ Positive Beta } & 3.936 & 2.757 & 6.402 & 4.328 & 2.659 & 7.682 \\
\hline & $(0.136)$ & $(0.129)$ & $(0.317)$ & $(0.112)$ & $(0.110)$ & $(0.247)$ \\
\hline Panel C: Beta Quant & \multicolumn{3}{|c|}{ Overall Crisis Periods } & \multicolumn{3}{|c|}{ Overall non-Crisis Periods } \\
\hline \multirow[t]{2}{*}{ Lowest } & 5.600 & 2.907 & 10.520 & 3.844 & -0.351 & 12.705 \\
\hline & $(0.109)$ & $(0.105)$ & $(0.230)$ & $(0.062)$ & $(0.050)$ & $(0.143)$ \\
\hline \multirow[t]{2}{*}{ Highest } & 5.044 & 5.150 & 4.783 & 4.315 & 2.228 & 9.055 \\
\hline & $(0.112)$ & $(0.114)$ & $(0.271)$ & $(0.071)$ & $(0.063)$ & $(0.176)$ \\
\hline Panel D: Beta Quant & \multicolumn{3}{|c|}{ Black Monday Crisis (1987) } & \multicolumn{3}{|c|}{ Dotcom Crisis (2000-2002) } \\
\hline \multirow[t]{2}{*}{ Lowest } & 2.639 & -1.661 & 9.480 & 5.862 & 1.313 & 13.622 \\
\hline & $(0.264)$ & $(0.235)$ & $(0.521)$ & $(0.187)$ & $(0.148)$ & $(0.394)$ \\
\hline \multirow[t]{3}{*}{ Highest } & 2.082 & -0.442 & 6.001 & 6.478 & 6.369 & 6.926 \\
\hline & $(0.353)$ & $(0.347)$ & $(0.693)$ & $(0.176)$ & $(0.158)$ & $(0.624)$ \\
\hline & \multicolumn{3}{|c|}{ Global Credit Crisis (2007-2009) } & & & \\
\hline \multirow[t]{2}{*}{ Lowest } & 6.637 & 5.933 & 8.088 & & & \\
\hline & $(0.154)$ & $(0.165)$ & $(0.323)$ & & & \\
\hline \multirow[t]{2}{*}{ Highest } & 5.025 & 5.917 & 3.137 & & & \\
\hline & $(0.143)$ & $(0.164)$ & $(0.276)$ & & & \\
\hline
\end{tabular}

Notes: Table 11 reports the results of the LSV herding measures at the overall, buy and sell sub-group levels. Overall, buy and sell herding measures are shown for stocks' betas in combination with different market conditions. Betas for each stock traded by US mutual funds have been calculated using EVENTUS, which uses the CRSP database to find quarterly stocks' betas. After calculating the quarterly betas of the stocks, I sort all the betas into five quantiles each quarter. The quantile with the lowest $20 \%$ of betas is called the lowest quant and the quantile with the highest $20 \%$ of betas is called the highest quant. The results are in percentages, standard errors are in parentheses and the T-tests are two-tailed. All results are statistically significant at the $1 \%$ level.

Source: Thomson Financial/CDA-Spectrum 


\section{Conclusion}

Using quarterly holdings of US equity MFs, I investigate the herding dynamics in the long-term trading behavior of US equity MFs over the period 1980 to 2009. Consistent with the mainstream literature, I also use the LSV herding measure to calculate US equity MFs' herding and observe increased herding in their long-term trading behavior. I focus on funds' styles, market volatility, the increased participation of MFs in the financial markets and MFs' size/capitalization as possible determinants of this increased herding in their trading behavior. Our findings show that herding varies significantly across different styles of MFs. Unclassified MFs appear to herd most; however, being dominant in terms of number and capitalization, growth MFs are found to explain most of the overall increased herding in the long-term trading behavior of the MF industry. I also observe slight variations in herding behavior across different deciles of funds' capitalizations (size-deciles), where large MFs appear to herd slightly less than small MFs. I argue that small MFs mimic the trading strategies of large MFs and thus experience higher levels of herding compared to large MFs.

I find that US equity MFs have risk and liquidity preferences in their herding behavior; for instance, they show a significantly higher demand for low-beta compared with high-beta stocks as well as small-sized compared with large-sized stocks. This result answers one of our hypotheses that in the long term, US equity mutual funds limit themselves to certain stock characteristics. The higher demand for smaller-sized stocks confirms the presence of the small-firm-effect anomaly.

Market volatility is found to be one of the important drivers of increased long-term herding in MFs' trading behavior; bear market conditions especially appear to experience much higher herding, about two percent, compared with bullish environments. I observe significantly higher herding levels during crisis periods, which is consistent with the findings of Patterson and Sharma (2004) and inconsistent with the results of Choe et al. (1999).

In summary this research contributes to the existing literature in several ways. First, I investigate herding over time and provide empirical evidence of increased herding in the trading behavior of institutional investors. Second, I focus on mutual funds' styles, market capitalization, participation in the financial markets and market realized volatility as determinants of significant herding over time. Third, I analyze the herding behavior of MFs during both bull and bear markets to see whether herding in the trading behavior of MFs co-moves with market conditions. Last, I extend the existing literature on the characteristics of herding, for instance, stocks' sensitivity to market movements (beta).

Since this article focuses on a detailed investigation of herding dynamics over time and its determinants, exploring the institutional herding effect on security prices is beyond the scope of this article and is left for the future research. Another limitation of this research is the quarterly data and therefore availability of a higher frequency data is likely to produce more convincing results.

\section{References}

Carhart, M. M. (1997). On persistence in mutual fund performance. The Journal of finance, 52(1), 57-82. https://doi.org/10.1111/j.1540-6261.1997.tb03808.x

Choe, H., Kho, B.-C., \& Stulz, R. M. (1999). Do foreign investors destabilize stock markets? The Korean experience in 1997. Journal of Financial Economics, 54(2), 227-264. https://doi.org/10.1016/s0304-405x(99)00037-9

Christie, W. G., \& Huang, R. D. (1995). Following the pied piper: Do individual returns herd around the market? Financial Analysts Journal, 51(4), 31-37. https://doi.org/10.2469/faj.v51.n4.1918

Collins, D. W., Kothari, S. P., \& Rayburn, J. D. (1987). Firm size and the information content of prices with respect to earnings. Journal of Accounting and Economics, 9(2), 111-138. https://doi.org/10.1016/0165-4101(87)90002-4

Daniel, K., Grinblatt, M., Titman, S., \& Wermers, R. (1997). Measuring mutual fund performance with characteristic-based benchmarks. The Journal of finance, 52(3), 1035-1058. https://doi.org/10.1111/j.1540-6261.1997.tb02724.x

Dasgupta, A., Prat, A., \& Verardo, M. (2011). Institutional Trade Persistence and Long-Term Equity Returns. The Journal of finance, 66(2), 635-653. https://doi.org/10.1111/j.1540-6261.2010.01644.x

Dasgupta, S., Gan, J., \& Gao, N. (2010). Transparency, price informativeness, and stock return synchronicity: Theory and evidence. https://doi.org/10.1017/s0022109010000505

Ding, B., \& Wermers, R. (2004). Mutual fund" stars": the performance and behavior of US fund managers. Unpublished paper, University of Maryland. https://doi.org/10.2139/ssrn.687273 
Falkenstein, E. G. (1996). Preferences for stock characteristics as revealed by mutual fund portfolio holdings. The Journal of finance, 51(1), 111-135. https://doi.org/10.1111/j.1540-6261.1996.tb05204.x

Frazzini, A., \& Lamont, O. A. (2008). Dumb money: Mutual fund flows and the cross-section of stock returns. Journal of Financial Economics, 88(2), 299-322. https://doi.org/10.1111/j.1540-6261.1996.tb05204.x

Glode, V. (2011). Why mutual funds "underperform". Journal of Financial Economics, 99(3), 546-559. https://doi.org/10.1016/j.jfineco.2010.10.008

Gompers, P. A., \& Metrick, A. (1998a). How are large Institutions different from other investors? Why do these Differences Matter? , 1. https://doi.org/10.2139/ssrn.93660

Gompers, P. A., \& Metrick, A. (1998b). Institutional investors and equity prices. Retrieved from National bureau of economic research. https://doi.org/10.3386/w6723

Grinblatt, M., \& Titman, S. (1989). Mutual fund performance: An analysis of quarterly portfolio holdings. Journal of business, 393-416. https://doi.org/10.1086/296468

Grinblatt, M., \& Titman, S. (1993). Performance measurement without benchmarks: An examination of mutual fund returns. Journal of business, 47-68. https://doi.org/10.1086/296593

Grinblatt, M., Titman, S., \& Wermers, R. (1995). Momentum investment strategies, portfolio performance, and herding: A study of mutual fund behavior. The American economic review, 1088-1105. https://doi.org/10.1086/296468

Hwang, S., \& Salmon, M. (2004). Market stress and herding. Journal of Empirical Finance, 11(4), 585-616. https://doi.org/10.1016/j.jempfin.2004.04.003

Lakonishok, J., Shleifer, A., \& Vishny, R. W. (1992). The impact of institutional trading on stock prices. Journal of Financial Economics, 32(1), 23-43. https://doi.org/10.1016/0304-405x(92)90023-q

Lobao, J., \& Serra, A. P. (2007). Herding behavior: Evidence from portuguese mutual funds Diversification and portfolio management of mutual funds (pp. 167-197): Springer. https://doi.org/10.1057/9780230626508_8

Nofsinger, J. R., \& Sias, R. W. (1999). Herding and feedback trading by institutional and individual investors. The Journal of finance, 54(6), 2263-2295. https://doi.org/10.1111/0022-1082.00188

Patterson, D. M., \& Sharma, V. (2004). Intraday trading: Herding versus market efficiency”. Working Paper,(August). https://doi.org/10.2139/ssrn.2603399

Perold, A. F., \& Salomon Jr, R. S. (1991). The right amount of assets under management. Financial Analysts Journal, 47(3), 31-39. https://doi.org/10.2469/faj.v47.n3.31

Pirinsky, C. (2002). Herding and contrarian trading of institutional investors. Working paper, Texas A\&M University.

Puckett, A., \& Yan, X. S. (2008). Short-term institutional herding and its impact on stock prices. Available at SSRN 972254. https://doi.org/10.2139/ssrn.1108092

Sias, R. W. (2004). Institutional herding. Review of financial studies, 17(1), $165-206$. https://doi.org/10.1093/rfs/hhg035

Stanley, H. E., Gabaix, X., Gopikrishnan, P., \& Plerou, V. (2006). Economic fluctuations and statistical physics: the puzzle of large fluctuations. Nonlinear Dynamics, 44(1-4), 329-340. https://doi.org/10.1007/s11071-006-2017-2

Wahal, S., \& Wang, A. Y. (2011). Competition among mutual funds. Journal of Financial Economics, 99(1), 40-59. https://doi.org/10.1016/j.jfineco.2010.08.012

Wermers, R. (1999). Mutual fund herding and the impact on stock prices. The Journal of finance, 54(2), 581-622. https://doi.org/10.1016/j.jfineco.2010.08.012

Wermers, R. (2000). Mutual fund performance: An empirical decomposition into stock-picking talent, style, transactions costs, and expenses. The Journal of finance, 55(4), 1655-1703. https://doi.org/10.1111/0022-1082.00263

Wylie, S. (2005). Fund manager herding: A test of the accuracy of empirical results using UK data. The Journal of Business, 78(1), 381-403. https://doi.org/10.1086/426529 


\section{Appendix A}

\begin{tabular}{lcllll}
\hline \multicolumn{6}{c}{ Correlation between different variables } \\
\hline & $\begin{array}{c}\text { Quarterly } \\
\text { herding }\end{array}$ & $\begin{array}{l}\text { No. of } \\
\text { funds }\end{array}$ & $\begin{array}{l}\text { quarterly } \\
\text { assets }\end{array}$ & $\begin{array}{l}\text { No. of } \\
\text { securities }\end{array}$ & $\begin{array}{l}\text { Quarterly } \\
\text { volatility }\end{array}$ \\
Quarterly & 1 & & & & \\
Herding & & & & & \\
No. of funds & 0.5067 & 1 & & & \\
quarterly assets & 0.1986 & 0.4408 & 1 & & \\
No. of securities & 0.4387 & 0.5917 & 0.4763 & 1 & \\
Volatility & -0.056 & 0.266 & 0.3547 & 0.2303 & 1 \\
\hline
\end{tabular}

Notes: Table 1 presents the correlation between different potential factors that may affect the quarterly herding. Here Quarterly herding is the average LSV quarterly herding, No. of funds are the MFs that involved in trading during quarter, No. of securities represents the securities traded during a certain quarter and volatility is CBOX quarter-VIX.

\section{Notes}

Note 1. Including credit risks, liquidity risks, funding risks, stock market volatility, etc.

Note 2. Institutions account for about 64\% of the market value of the CRSP, (S. Dasgupta, Gan, \& Gao, 2010).

Note 3. Financial commentators and investors often say that herding in the financial markets is increasing (Patterson \& Sharma, 2004).

Note 4. User's Guide to Thomson Reuters.

Note 5. As per the User's Guide by Thomson Reuters.

Note 6. Actively managed funds incur substantially higher trading costs than index funds (Wermers, 2000).

Note 7. The quarterly volatility of the S\&P 500 Index has been used as a proxy for market volatility. 